\title{
Conformational Properties of a Peptidic Catalyst - Insights from NMR Spectroscopic Studies
}

\author{
Carla Rigling, ${ }^{\mathrm{a}}$ Jessica K. Kisunzu, ${ }^{\mathrm{a}}$ Jörg Duschmalé, ${ }^{\mathrm{a}, \mathrm{b}}$ Daniel Häussinger, ${ }^{\mathrm{b}}$ Markus Wiesner, ${ }^{\mathrm{b}}$ \\ Marc-Olivier Ebert, ${ }^{\mathrm{a}, *}$ Helma Wennemers ${ }^{\mathrm{a}, *}$ \\ ${ }^{a}$ Laboratorium für Organische Chemie, ETH Zürich, D-CHAB, Vladimir-Prelog-Weg 3, 8093 Zürich, Switzerland. \\ ${ }^{\mathrm{b}}$ Department of Chemistry, University of Basel, St. Johanns-Ring 19, 4056 Basel, Switzerland
}

\begin{abstract}
Peptides have become valuable as catalysts for a variety of different reactions but little is known about the conformational properties of peptidic catalysts. We investigated the conformation of the peptide $\mathrm{H}-\mathrm{DPro}_{\mathrm{P}} \mathrm{Pro}-\mathrm{Glu}-\mathrm{NH}_{2}$, a highly reactive and stereoselective catalyst for conjugate addition reactions, and the corresponding enamine intermediate in solution by NMR spectroscopy and computational methods. The combination of nuclear Overhauser effects (NOEs), residual dipolar couplings (RDCs), J-couplings, and temperature coefficients revealed that the tripeptide adopts a single predominant conformation in its ground state. The structure is a type I $\beta$-turn, which gains stabilization from three hydrogen bonds that are cooperatively formed between all functional groups (secondary amine, carboxylic acid, amides) within the tripeptide. In contrast, the conformation of the enamine intermediate is significantly more flexible. The conformational ensemble of the enamine is still dominated by the $\beta$-turn but the backbone and the side chain of the glutamic acid residue are more dynamic. Key to the switch between rigidity and flexibility of the peptidic catalyst is the $\mathrm{CO}_{2} \mathrm{H}$ group in the side chain of the glutamic acid residue, which acts as a lid that can open and close. As a result, the peptidic catalyst is able to adapt to the structural requirements of the intermediates and transition states of the catalytic cycle. These insights might explain the robustness and high reactivity of the peptidic catalyst, which exceeds that of other secondary amine-based organocatalysts. The data suggest that a balance between rigidity and flexibility, which is reminiscent of the dynamic nature of enzymes, is beneficial for peptidic catalysts and other synthetic catalysts.
\end{abstract}

\section{Introduction}

In recent years more and more catalytically active peptides have been developed for different asymmetric reactions. ${ }^{1-11}$ These catalysts are composed of amino acids, the building blocks of enzymes, but have molecular weights that are comparable to those of synthetic man-made catalysts. Several examples showed that peptidic catalysts can have impressive stereo-, chemo-, and regioselectivities, features that are hallmarks of enzymes. ${ }^{2-11}$ Yet, peptidic catalysts often have also a broad substrate scope, a highly desirable feature of synthetic catalysts that is rarely observed for enzymes. Thus, these peptides combine features of enzymes and man-made low-molecular-weight catalysts.

Whereas several studies have explored the dependence of the reactivity, stereo-, chemo-, and regioselectivities of peptidic catalysts on their amino acid sequence, significantly less is known about their conformational features. ${ }^{1}$ In general, $\alpha$-peptides of small or medium size (3-20 residues) are conformationally flexible and able to adopt several conformers that are in rapid equilibrium unless constraints are implemented. ${ }^{12}$ Recent studies by Miller as well as Thiele and Schreiner showed that even peptidic catalysts with rigidifying turn motifs adopt more than one structure but can be highly stereoselective. ${ }^{13-16}$ Despite these examples, there is still little knowledge about the conformational features that are ideal to achieve highly reactive and stereoselective peptidic catalysts.
Our group introduced tripeptides of the type Pro-Pro-Xaa as catalysts for aldol reactions and related $\mathrm{C}-\mathrm{C}$ bond formations. $^{5-11}$ For example, H-DPro-Pro-Glu- $\mathrm{NH}_{2} \mathbf{1}$ is a highly stereoselective and reactive catalyst for conjugate addition reactions of aldehydes to nitroolefins. ${ }^{6-8}$ As little as $1 \mathrm{~mol} \%$, or less, of the tripeptide is necessary to obtain a broad range of addition products in high yields and stereoselectivities. This level of reactivity is remarkable as other chiral amine-based organocatalysts, including other peptidic catalysts, typically require catalyst loadings of 10-30 mol\%. ${ }^{1,17}$ These findings suggest that not only the functional groups but also the conformational features of Pro-Pro-Xaatype peptides are important for their stereoselectivity and reactivity. The tripeptides are also so robust that immobilized analogs of 1 can be reused countless times, even in a flow reactor, without a noticeable decrease in their catalytic performance. ${ }^{18}$ A similar robustness has not been achieved with other amine-based catalysts ${ }^{17,19}$ further indicating that detailed insight into the behavior of $\mathbf{1}$ is valuable for a deeper understanding of organocatalysis with chiral amines.

Mechanistic studies elucidated that the conjugate addition reactions catalyzed by 1 proceed via an enamine intermediate, which is involved in the subsequent rate- and enantioselectivity-determining $\mathrm{C}-\mathrm{C}$ bond formation with the nitroolefin (Scheme 1). ${ }^{8,20,21}$ Protonation of the resulting iminium nitronate (1-Nit) by an intramolecular proton transfer from the carboxylic acid moiety and hydrolysis of the imine provides the product and completes the catalytic cycle. ${ }^{21}$ Thus, 
knowledge on the conformation of the ground state of catalyst $\mathbf{1}$ and the enamine intermediate 1-En is important for a deeper understanding of the observed high stereoselectivity, reactivity, and robustness of the peptidic catalysts. ${ }^{22}$

A recent study showed that the higher the trans:cis ratio around the tertiary DPro-Pro amide bond of DPro-Pro-Xaatype catalysts is, the higher is their dia- and enantioselectivity. ${ }^{23}$ Crystal structures of DPro-Pro-Xaa peptides all show a $\beta$-turn-like structure with a significant degree of structural variability at the $\mathrm{C}$-terminal residue. ${ }^{24}$ However, crystal structures are per se static and therefore not able to provide information about the dynamic nature of the peptides.

Scheme 1. Catalytic cycle of conjugate addition reactions of aldehydes to nitroolefins catalyzed by H-DPro-Pro-Glu- $\mathrm{NH}_{2}$ (1).
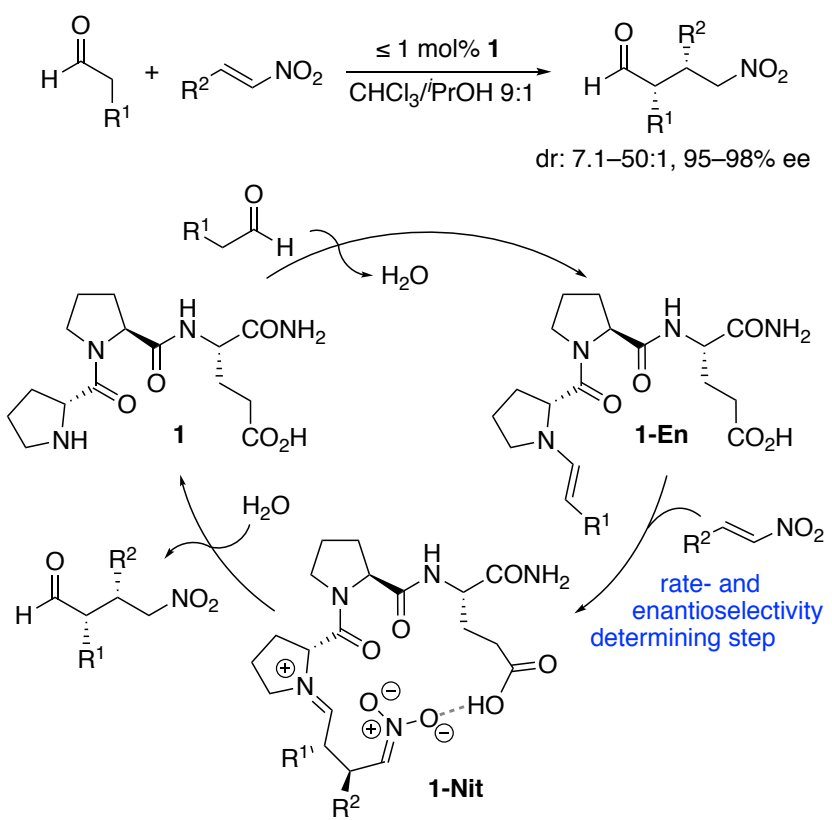

Herein, we explored the conformational properties of peptidic catalyst 1 and of an enamine derived from H-DPro-Pro-Glu$\mathrm{NH}_{2}$ (1-En) in solution by NMR spectroscopy under nearcatalytic conditions. In addition to nuclear Overhauser effects (NOEs) and J-couplings $\left({ }^{3} \mathrm{~J}_{\mathrm{H}, \mathrm{H}}\right.$ and $\left.{ }^{3} \mathrm{~J}_{\mathrm{C}, \mathrm{H}}\right)$, the conformational analyses included residual dipolar couplings (RDCs) and variable temperature experiments. The data revealed that $\mathbf{1}$ adopts a well-defined turn conformation that is stabilized by three intramolecular H-bonds, including a salt-bridge that shields the reactive amino group. In contrast, the conformation of the intermediate enamine 1-En is distinctly more flexible. These findings were supported by computational studies and imply that fine-tuning the balance between rigidity and flexibility along the catalytic cycle offers new opportunities for catalyst design.

\section{Results and Discussion}

We sought to gain insight into the conformation of the ground state of peptide 1 and the enamine intermediate (1-En), which is involved in the rate- and enantioselectivity-determining step of the conjugate addition reaction (Scheme 1). ${ }^{8,20,21}$ Enamines such as 1-En that contain an acidic proton are highly reactive and therefore difficult to characterize. ${ }^{25}$ We therefore started by analyzing the structure of the ground state of H-DPro-ProGlu- $\mathrm{NH}_{2}$ (1). The optimal solvent for conjugate addition reactions catalyzed by $\mathrm{H}-\mathrm{DPro}-\mathrm{Pro}-\mathrm{Glu}-\mathrm{NH}_{2}$ (1) was found to be $\mathrm{CHCl}_{3}: i \mathrm{PrOH} 9: 1 .^{6}$ To stay as close as possible to the catalytic conditions all spectra were recorded in a solution of $\mathrm{CDCl}_{3}: \mathrm{CD}_{3} \mathrm{OH}$ 9:1. ${ }^{26} \mathrm{~A}$ combination of HSQC, TOCSY, DQF-COSY, and HMBC allowed for the assignment of all carbon and proton resonances of peptide 1, except for the diastereotopic protons of the proline residues that were assigned based on a J-coupling analysis. ${ }^{27,28}$ The assignment of the diastereotopic protons at $\mathrm{C} \gamma$ of the Glu residue $\left(\mathrm{E}-\mathrm{H} \gamma^{1}\right.$ and $\mathrm{E}-\mathrm{H} \gamma^{2}$ ) was only possible via an extensive analysis using a combination of NOEs, RDCs, and J-couplings. ${ }^{27}$ The crosspeak volumes in the ROESY spectrum were converted into distances by calibration with known distances, which allowed for a quantitative analysis of the NOEs (Figure 1a). ${ }^{27}$ All spectra show one major set of signals $(>100: 1)$, which was unambiguously assigned based on characteristic ROESY correlations to a conformation where the tertiary amide bond between the two proline residues is trans.

Backbone conformation of $\mathrm{H}$-DPro-Pro-Glu-NH $\mathrm{N}_{2}$ (1). The DPro-Pro motif is a turn-inducing element in cyclic and linear peptides. ${ }^{24,29-32}$ When embedded in a peptide chain, the turn is stabilized by two $\mathrm{H}$-bonds that form consecutive $\beta$-turns. ${ }^{29,32}$ In case of catalyst $\mathbf{1}$ where this motif is at the $\mathrm{N}$-terminus only one $\mathrm{H}$-bond can form. To evaluate whether peptide $\mathbf{1}$ adopts a turn conformation in solution we started by analyzing the interresidual NOEs (Figure 1a). Strong sequential NOEs corresponding to distances of $2.2 \AA$ and $2.7 \AA$, respectively, were observed between the proton at $\mathrm{C} \alpha$ of the N-terminal DPro residue ( $\mathrm{p}-\mathrm{H} \alpha)$ and the protons at $\mathrm{C} \delta$ of the central LPro residue $\left(\mathrm{P}-\mathrm{H} \delta^{1} / \mathrm{H}^{2}\right)$. Additional NOEs corresponding to distances of $2.6 \AA$ and $3.0 \AA$, respectively, were identified between the protons at $\mathrm{C} \beta$ of DPro $\left(\mathrm{p}-\mathrm{H} \beta^{1} / \mathrm{H} \beta^{2}\right)$ and $\mathrm{P}-\mathrm{H} \delta^{1}$, the proton at $\mathrm{C} \delta$ of LPro on the bottom face. These NOEs validate the trans amide bond between the proline residues and suggest a $\psi$ dihedral angle close to $-120^{\circ}$ for the DPro residue. ${ }^{32}$

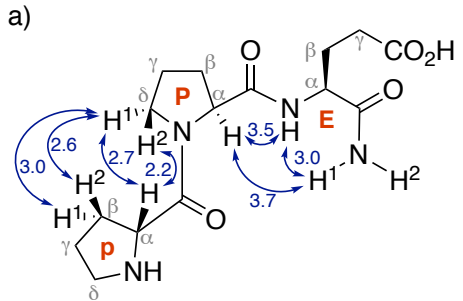

b)

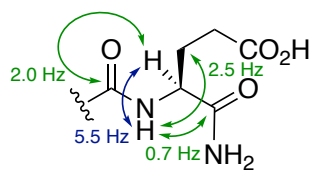

Figure 1. a) Selected NOEs of $\mathbf{1}$ with distances in $\AA$. b) ${ }^{3} \mathrm{~J}_{\mathrm{H}, \mathrm{H}}$ (blue) and ${ }^{3} \mathrm{~J}_{\mathrm{C}, \mathrm{H}}$ (green) coupling constants of the Glu residue indicative of a type I $\beta$-turn.

A strong NOE was also found between the amide NH of the glutamic acid residue and one of the $\mathrm{C}$-terminal amide protons $\left(\mathrm{E}-\mathrm{NH} / \mathrm{CONH}^{1}, 3.0 \AA\right)$ and a weaker NOE occurs between P$\mathrm{H} \alpha$ and $\mathrm{CONH}^{1}$ (3.7 $\AA$ ) (Figure 1a). These distances are characteristic of a $\beta$-turn conformation with a H-bond between 
the carbonyl group of the DPro residue and the amide proton of the C-terminal amide. ${ }^{33-35}$ Furthermore, the NOE-derived distance between $\mathrm{P}-\mathrm{H} \alpha$ and $\mathrm{E}-\mathrm{NH}$ of $3.5 \AA$ points to a type I $\beta$-turn conformation since a shorter distance would be expected for a type II $\beta$-turn, where the amide between the Pro and Glu residues is flipped by $180^{\circ} .{ }^{33-35}$ Further support for a type I $\beta$-turn came from analysis of the $\phi$ dihedral angle of the glutamic acid residue. This analysis was based on the ${ }^{3} \mathrm{~J}(\mathrm{E}-$ $\mathrm{NH}, \mathrm{E}-\mathrm{H} \alpha$ ) proton-proton coupling as well as the heteronuclear ${ }^{3} \mathrm{~J}_{\mathrm{C}, \mathrm{H}}$ couplings accessible by a combination of HSQCHECADE and refocused HMBC experiments. ${ }^{36}$ Although significantly more difficult to obtain than ${ }^{3} \mathrm{~J}_{\mathrm{H}, \mathrm{H}}$ coupling constants, the heteronuclear J-couplings provide essential information because the $\phi$ angle is often not sufficiently characterized by ${ }^{3} \mathrm{~J}_{\mathrm{HN}, \mathrm{H} \alpha}$ alone. ${ }^{34}$ The observed values of $5.5 \mathrm{~Hz}$ for ${ }^{3} \mathrm{~J}(\mathrm{E}-\mathrm{NH}, \mathrm{E}-\mathrm{H} \alpha)$ and $0.7 \pm 0.1 \mathrm{~Hz}$ for ${ }^{3} \mathrm{~J}(\mathrm{E}-\mathrm{NH}, \mathrm{E}-\mathrm{CO})$ were evaluated using the Karplus curves by Wang and Bax for $\phi$ dihedral angles in proteins (Figure S3). ${ }^{37}$ They are both in excellent agreement with a backbone dihedral angle $\phi$ of $290^{\circ}$, close to the value of $270^{\circ}$ expected for canonical type I $\beta$-turns (Figure S3). ${ }^{38}$ This finding is further corroborated by coupling constants ${ }^{3} \mathrm{~J}(\mathrm{E}-\mathrm{NH}, \mathrm{E}-\mathrm{C} \beta)$ and ${ }^{3} \mathrm{~J}(\mathrm{P}-\mathrm{CO}, \mathrm{E}-\mathrm{H} \alpha)$ of $2.5 \pm 0.2 \mathrm{~Hz}$ and $2.0 \pm 0.1 \mathrm{~Hz}$, respectively.

Conformation of the glutamic acid side chain in peptide 1. Vicinal coupling constants between protons at $\mathrm{C} \alpha, \mathrm{C} \beta$, and $\mathrm{C} \gamma$ in glutamic acid residues are close to $7 \mathrm{~Hz}$ if the side-chain is completely flexible. In peptide $\mathbf{1}$ these coupling constants are between $3.8-4.5 \mathrm{~Hz}$ (Figure 2). These small values suggest distinct conformational preferences of the side-chain dihedral angles $\chi^{1}$ and $\chi^{2}$ within the Glu residue side chain. The complete set of experimentally available coupling constants, also incorporating ${ }^{3} \mathrm{~J}_{\mathrm{C}, \mathrm{H}}$ couplings, is in good agreement with glutamic acid side chain dihedral angles of $\sim 60^{\circ}$ for $\chi^{1}$ and $\sim 300^{\circ}\left(-60^{\circ}\right)$ for $\chi^{2}$ (Figures 2 and S4). ${ }^{39}$
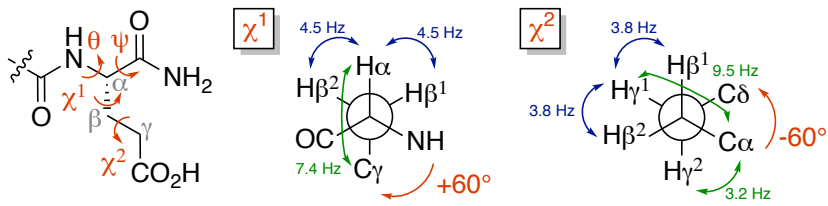

Figure 2. Dihedral angles of the side chain of the Glu residue derived from ${ }^{3} \mathrm{~J}_{\mathrm{H}, \mathrm{H}}$ (blue) and ${ }^{3} \mathrm{~J}_{\mathrm{C}, \mathrm{H}}$ (green) coupling constants.

Importantly, the observed ${ }^{3} \mathrm{~J}_{\mathrm{C}, \mathrm{H}}$ couplings of $7.4 \mathrm{~Hz}$ for ${ }^{3} \mathrm{~J}(\mathrm{E}-$ $\mathrm{C} \gamma, \mathrm{E}-\mathrm{H} \alpha)$ and $9.5 \mathrm{~Hz}$ for ${ }^{3} \mathrm{~J}\left(\mathrm{E}-\mathrm{C} \alpha, \mathrm{E}-\mathrm{H} \gamma^{1}\right)$ are in close proximity to the global maximum of the respective Karplus curves (Figure S4). Thus, significant contributions from other conformations can be excluded. The resulting torsion angles indicate a conformation in which the side chain of the Glu residue points towards the DPro-Pro moiety.

Residual Dipolar Couplings (RDCs) and Simulated Annealing. The analysis of NOEs and coupling constants suggests that both the backbone and the glutamic acid residue side chain of tripeptide $\mathbf{1}$ adopt a well-defined dominant conformation in solution. Using a simulated annealing calculation we wanted to probe how well the overall peptide conformation is defined by the experimental data and whether the NOE-derived distances are self-consistent and in agreement with the J-coupling-derived dihedral angles. Given a sufficiently high density of NMR restraints, a self-consistent set of NOE-derived (especially long-range) distances and good agreement between distances and J-couplings are indicative of a homogeneous conformational ensemble dominated by a single structure. Yet, conventional NMR restraints are usually sparse for small molecules and it is important to complement these data with other sources of structural information for cross-validation. We therefore also determined residual dipolar couplings (RDCs) that provide insight into the orientation of bond vectors relative to a global frame of reference. $^{40,41}$ In contrast to J-couplings and NOEs that both give short-range insight (usually up to 3 bonds and $5 \AA$, respectively), RDCs provide long-range information. RDCs can only be observed if the molecule under study is partially oriented (aligned) with respect to an external magnetic field. ${ }^{40,41}$ While it is common to use RDCs in protein structure determination, only a few studies have included RDCs in the conformational analysis of peptides. ${ }^{16,41,42} \mathrm{We}$ succeeded in aligning peptide 1 in stretched cross-linked poly(vinyl acetate) (PVAc), ${ }^{43}$ an alignment medium that is compatible with both chloroform and methanol, and observed in total 13 one-bond ${ }^{13} \mathrm{C}-{ }^{1} \mathrm{H}$ RDCs and two geminal ${ }^{1} \mathrm{H}-{ }^{1} \mathrm{H}$ RDCs in the range from $-13 \mathrm{~Hz}$ to $+18 \mathrm{~Hz}$ (Table S7).

All NOEs, RDCs, and the dihedral angles E- $\chi 1, E-\chi^{2}$, and E- $\phi$ were included as restraints in a simulated annealing calculation using XPLOR-NIH. $^{27,44}$, The resulting 48 structures are almost identical with respect to their backbone dihedral angles as well as the orientation of the glutamic acid residue side chain (Figure 3a). The identified global structure is in excellent agreement with all NMR spectroscopically derived restraints (e.g., RDCs in Figure 3b). ${ }^{27}$ This finding further corroborates that peptidic catalyst $\mathbf{1}$ adopts a dominant conformation in its ground state.

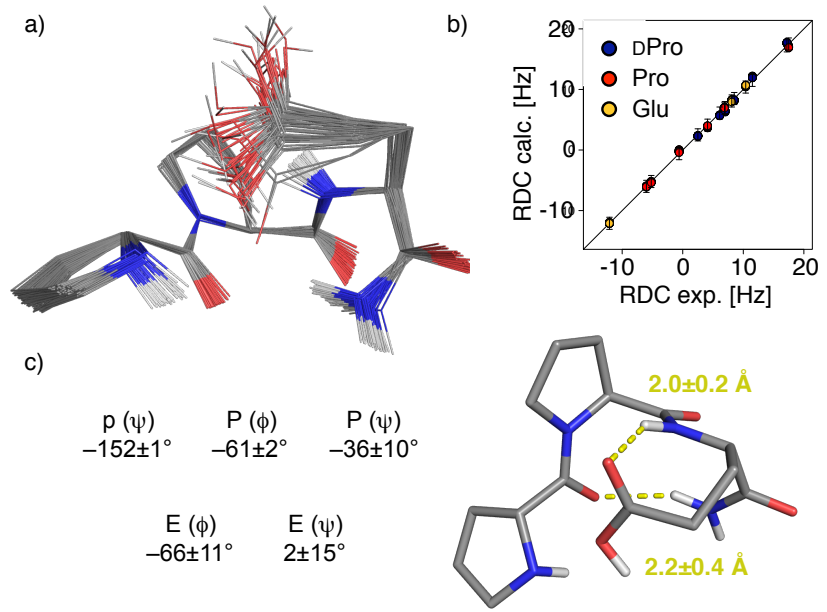

Figure 3. a) Bundle of the 48 structures obtained by simulated annealing using NOE-, dihedral angle-, and RDC-restraints. Superposition over all C-atoms of all 48 structures (RMSD: $0.18 \pm 0.09 \AA$ ). b) Plot of experimental versus back-calculated RDCs. c) Representative low energy structure and average backbone dihedral angles including standard deviation. 
The structure is a type I $\beta$-turn with a $\mathrm{H}$-bond between the $\mathrm{C}=\mathrm{O}$ of the $\mathrm{N}$-terminal DPro residues and the $\mathrm{C}$-terminal amide $\mathrm{NH}_{2}$ as indicated by $\mathrm{N}-\mathrm{H} \cdots \mathrm{O}$ distances of $<2.4 \AA$ and $\mathrm{N}-\mathrm{H} \cdots \mathrm{O}$ angles within $180^{\circ} \pm 35^{\circ}$ in 29 of the 48 calculated structures (Figure 3c). ${ }^{45}$ An additional hydrogen bond between the backbone $\mathrm{NH}$ and the carboxylic acid group of the glutamic acid residue occurs in 20 of the 48 calculated structures as judged by the same criteria for H-bonds. This intraresidual hydrogen bond is also indicated by the very low field chemical shift of the backbone $\mathrm{NH}$ of Glu, which appears at $9.8 \mathrm{ppm}$, whereas amide protons typically appear at values below $9 \mathrm{ppm}$. Noteworthy is also the short distance between the N-terminal amine and the carboxylic acid group of the glutamic acid side chain in all of the obtained structures. This close proximity suggests an interaction between these two moieties, which would explain the dominant conformation of the glutamic acid side chain and the well-defined overall structure of peptide 1 .

Probing the intramolecular interactions in peptide 1. To validate the predicted intramolecular $\mathrm{H}$-bonds, we monitored the temperature dependence of the ${ }^{1} \mathrm{H}$ chemical shift of the amide proton signals. The change of their chemical shift upon heating provides temperature coefficients $\left(\Delta \delta_{\mathrm{HN}} / \Delta \mathrm{T}\right)$ that are good indicators for intramolecular hydrogen bonds within peptides. ${ }^{46-48}$ We recorded ${ }^{1} \mathrm{H}$ NMR spectra of $\mathbf{1}$ from $-60{ }^{\circ} \mathrm{C}$ to $55^{\circ} \mathrm{C}$ and observed a linear correlation for all three amide $\mathrm{NH}$ protons up to a temperature of $\sim 25^{\circ} \mathrm{C}$; beyond $25^{\circ} \mathrm{C}$, a non-linear temperature dependence indicates a partial loss of secondary structure (Figure 4a). ${ }^{47}$ For consistency with later experiments (vide infra), the temperature coefficients were determined between $-60{ }^{\circ} \mathrm{C}$ and $10^{\circ} \mathrm{C} .{ }^{27}$ This resulted in small
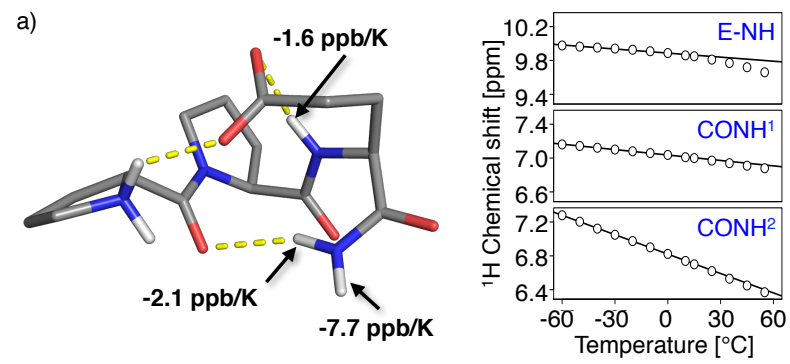

b)

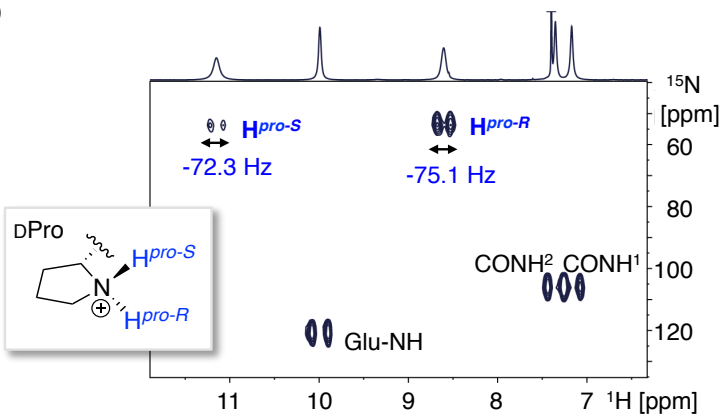

Figure 4. a) Temperature coefficients for the amide protons of 1 derived from the observed changes in their chemical shifts upon heating. b) Signals of the protons of the N-terminal amine in the ${ }^{15} \mathrm{~N}-\mathrm{HSQC}$ spectrum of $\mathbf{1}$ in $9: 1 \mathrm{CDCl}_{3}: \mathrm{CD}_{3} \mathrm{OH}$ recorded without decoupling at $-70^{\circ} \mathrm{C}$. values of $-1.6 \mathrm{ppb} / \mathrm{K}$ for $\mathrm{E}-\mathrm{NH}$ and $-2.1 \mathrm{ppb} / \mathrm{K}$ for $\mathrm{CONH}^{1}$, which are indicative of hydrogen bonded amides. ${ }^{49}$ In contrast, the other $\mathrm{C}$-terminal amide $\mathrm{NH}\left(\mathrm{CONH}^{2}\right)$ has a temperature coefficient of $-7.7 \mathrm{ppb} / \mathrm{K}$ that is typical for solvent exposed amide protons. ${ }^{48}$ These findings corroborate the calculated structure with intramolecular H-bonds formed by both amide NH groups.

The evaluation of the putative interaction between the $\mathrm{N}$ terminal amine and the carboxylic acid moiety of the Glu residue required studies at low temperature as their protons are not detectable at room temperature, most likely due to fast exchange with the solvent. Upon cooling the solution of peptide 1 in $\mathrm{CDCl}_{3}: \mathrm{CD}_{3} \mathrm{OH} 9: 1$ to $-70{ }^{\circ} \mathrm{C}$, two new broad signals at $8.6 \mathrm{ppm}$ and $11.1 \mathrm{ppm}$ became visible in the ${ }^{1} \mathrm{H}$ NMR spectrum (Figure 4b). A ${ }^{15} \mathrm{~N}$ HSQC spectrum confirmed the connectivity of both protons to the same nitrogen. The strong low field chemical shift of one of the protons is typical for a hydrogen-bonded ammonium ion $\mathrm{NH}$ moiety and supports the predicted interaction with the carboxylic acid group of the Glu residue. In agreement with this conclusion, the two protons exhibit different ${ }^{1} \mathrm{~J}_{\mathrm{H}, \mathrm{N}}$ coupling constants of $-72.3 \mathrm{~Hz}(\mathrm{H}$ at $11.1 \mathrm{ppm})$ and $-75.1 \mathrm{~Hz}$ ( $\mathrm{H}$ at $8.6 \mathrm{ppm}$, Figure $4 \mathrm{~b})$. The more positive coupling constant of the proton at low field indicates a longer $\mathrm{N}-\mathrm{H}$ bond and thus further supports a hydrogen bond. ${ }^{50}$ Interresidual NOEs of this $\mathrm{NH}$ with $\mathrm{p}-\mathrm{H} \alpha$ and $\mathrm{p}-\mathrm{H} \delta^{2}$, but not with $\mathrm{p}-\mathrm{H} \delta^{1}$, show that the proton involved in the $\mathrm{H}$-bond is on the $\mathrm{Si}$ face of the amine nitrogen $\left(\mathrm{H}^{\text {pro-S}}\right){ }^{27}$ These data show that the proton of the carboxylic acid is at least in part, if not fully, transferred to the $\mathrm{N}$-terminal amine of peptide $\mathbf{1}$ in a solution of $\mathrm{CDCl}_{3}: \mathrm{CD}_{3} \mathrm{OH}$.

Pyrrolidine ring puckering in peptide 1. The NMR spectroscopic data clearly show that the backbone and the glutamic acid side chain of peptide $\mathbf{1}$ adopt one predominant conformation and exhibit only a limited amount of flexibility. Finally, we examined whether the ring puckers of the proline residues also show a preference for a single conformation. Proline residues generally adopt either a $\mathrm{C} \gamma$-exo pucker, which is characterized by small ${ }^{3} \mathrm{~J}\left(\mathrm{H} \gamma^{2}, H \delta^{1}\right)$ values $(2-3 \mathrm{~Hz})$, or a $\mathrm{C} \gamma$-endo pucker, which exhibits small values for ${ }^{3} \mathrm{~J}\left(\mathrm{H} \alpha, \mathrm{H} \beta^{2}\right)$ and ${ }^{3} \mathrm{~J}\left(\mathrm{H} \gamma^{1}, \mathrm{H}^{2}\right)$ due to near $90^{\circ}$ dihedral angles. ${ }^{28,51,52}$ All observed ${ }^{3} \mathrm{~J}_{\mathrm{H}, \mathrm{H}}$ couplings of the DPro residue are in a range of $7.2-9.5 \mathrm{~Hz}{ }^{27}$ This indicates flexibility of the proline ring without preference for $\mathrm{C} \gamma$-exo or $\mathrm{C} \gamma$-endo puckering. For the Pro residue, values of $3.6 \mathrm{~Hz}$ for ${ }^{3} \mathrm{~J}\left(\mathrm{H} \alpha, \mathrm{H} \beta^{2}\right)$ and of $4.5 \mathrm{~Hz}$ for ${ }^{3} \mathrm{~J}\left(\mathrm{H} \gamma^{1}, \mathrm{H} \delta^{2}\right)$ were observed and are close to the range expected for an exclusive $\mathrm{C} \gamma$-endo pucker. Yet, the slightly elevated coupling constants also suggest a smaller but significant population of $\mathrm{C} \gamma$-exo pucker and thus again point to a dynamic equilibrium between the two ring conformations. ${ }^{27}$

Overall, the NMR spectroscopic data show that tripeptide 1 adopts one major conformation that is stabilized by three intramolecular hydrogen bonds. Thus, the ground state of catalyst $\mathbf{1}$ is a well-defined structure, where only the pyrrolidine rings of the two proline residues exhibit a significant degree of flexibility. 
Synthesis and NMR spectroscopic analysis of enamine 1En'. Previous mechanistic studies had shown that the enamine intermediate 1-En is involved in the rate- and enantioselectivity-determining step of the catalytic cycle..$^{20,21}$ The conformation of 1-En is therefore key for the stereochemical outcome of the reaction. Enamines formed by amine-based catalysts that bear an acidic moiety are highly reactive, in particular in protic solvents, and therefore difficult to characterize. ${ }^{25,53}$ Prior structural studies on enamines derived from organocatalysts (e.g., proline and prolinol-based catalysts) were mainly carried out in aprotic solvents (e.g. DMSO, DMF, acetonitrile, $\left.\mathrm{CDCl}_{3}\right) .^{25,54-58}$ In contrast, a detailed conformational analysis of an enamine derived from an acidic proton-containing catalyst in a protic solvent has so far remained elusive. ${ }^{59,23}$ Thus, analysis of the conformation of 1-En was expected to be challenging. Indeed, initial attempts to characterize an enamine formed by peptide 1 with butanal failed, as the enamine did not form quantitatively. We succeeded to obtain the resonance-stabilized enamine 1-En from catalyst 1 by reaction with phenylacetaldehyde (1.2 equiv.) in dry $\mathrm{CDCl}_{3}: \mathrm{CD}_{3} \mathrm{OH} 9: 1$. The water formed in the condensation reaction was trapped by activated powdered molecular sieves $(4 \AA)$ that were added to the NMR tube.

The ${ }^{1} \mathrm{H}$ NMR spectrum of 1-En' shows the characteristic signals of an enamine species along with unreacted aldehyde and a hemiacetal resulting from reaction of deuterated methanol with the aldehyde. At room temperature, the the enamine was not sufficiently stable and formation of side products further complicated the analysis of the NMR spectra. $^{60}$ Thus, more detailed studies were carried out at $-20^{\circ} \mathrm{C}$, where side products formed only to a minimal extent even after $4-5 \mathrm{~h}$. Unfortunately, enamine 1-En' is not sufficiently stable to allow for the measurement of RDCs in cross-linked PVAc since the swelling process to obtain the stretched gel takes several days. Thus, the structural analysis relied solely on data collected in isotropic environment. Resonance assignment of enamine 1-En' was straightforward, using a combination of two-dimensional NMR experiments as well as comparison with the spectra of $1{ }^{27}$ The ROESY crosspeak volumes were converted into distances by the same method as used for peptide $\mathbf{1}$.

Conformation of the enamine moiety of 1-En'. We started by analyzing the conformation of the enamine moiety of 1-En'. The two signals of the enamine-protons $\mathrm{H} 1$ and $\mathrm{H} 2$ appear in the ${ }^{1} \mathrm{H}$ NMR spectrum at $5.2 \mathrm{ppm}$ and $6.9 \mathrm{ppm}$ as doublets with a coupling constant of $13.9 \mathrm{~Hz}$, which is indicative for an $E$-configured enamine. Their connectivity was confirmed by a cross-peak in the DQF-COSY spectrum. The ROESY spectrum shows a strong NOE between $\mathrm{H} 1$ and the proton at $\mathrm{C} \alpha$ of the DPro residue $(\mathrm{p}-\mathrm{H} \alpha)$, but only a weak $\mathrm{NOE}$ of $\mathrm{H} 1$ with the protons at $\mathrm{C} \delta$ of DPro $\left(\mathrm{p}-\mathrm{H} \delta^{1} / \mathrm{H}^{2}\right)$. Conversely, $\mathrm{H} 2$ has strong NOEs with $\mathrm{p}-\mathrm{H} \delta^{1} / \mathrm{H}^{2}$ and only a weak NOE with p-H $\alpha$ (Figure 5). ${ }^{27}$
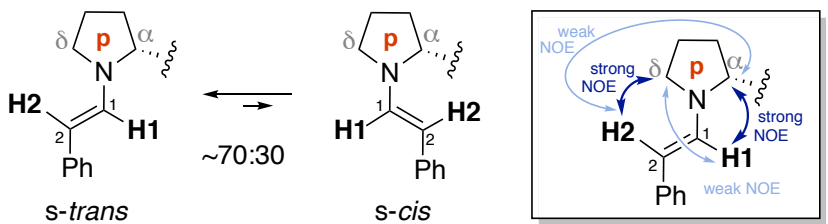

Figure 5. Equilibrium between s-trans and s-cis conformers of enamine 1-En' and observed NOEs.

These findings indicate that the conformation of the enamine moiety in 1-En' is predominantly s-trans. Comparison of the NOE-derived $\mathrm{H} 1 / \mathrm{p}-\mathrm{H} \alpha$ and $\mathrm{H} 2 / \mathrm{p}-\mathrm{H} \delta^{1} / \mathrm{H} \delta^{2}$ distances with pure $\mathrm{s}$-cis and s-trans enamine structures that were generated computationally suggests a s-trans:s-cis conformer ratio of approximately $70: 30 .^{27,55,58}$

Backbone conformation of the enamine 1-En'. Next we explored whether the structural features observed for $\mathbf{1}$ are still intact in enamine 1-En'. Within the DPro-Pro moiety, the NOE between $\mathrm{p}-\mathrm{H} \alpha$ and $\mathrm{P}-\mathrm{H}^{2}$ is weaker and the one between $\mathrm{p}$ $\mathrm{H} \beta^{1}$ and $\mathrm{P}-\mathrm{H} \delta^{1}$ is stronger in 1-En' compared to those in $\mathbf{1}$ (Figure 6a). These differences indicate that the two proline residues are either more twisted in 1-En' than in $\mathbf{1}$ or they reflect increased flexibility in the DPro-Pro unit of 1-En compared to that in $\mathbf{1}$. The NOEs between the C-terminal amide $\mathrm{CONH}^{1}$ and $\mathrm{E}-\mathrm{NH}$ as well as $\mathrm{P}-\mathrm{H} \alpha$ are weaker in the ROESY spectrum of 1-En' than those observed for $\mathbf{1}$ (Figure 6a). These longer distances indicate that 1-En' still adopts a $\beta$-turn conformation, but one that is less pronounced compared to that of the ground state catalyst $\mathbf{1}$. This finding is supported by a stronger NOE between $\mathrm{P}-\mathrm{H} \alpha$ and E-NH, which indicates a shorter distance between these two protons and points to a lower population of a type I $\beta$-turn. ${ }^{33-35}$
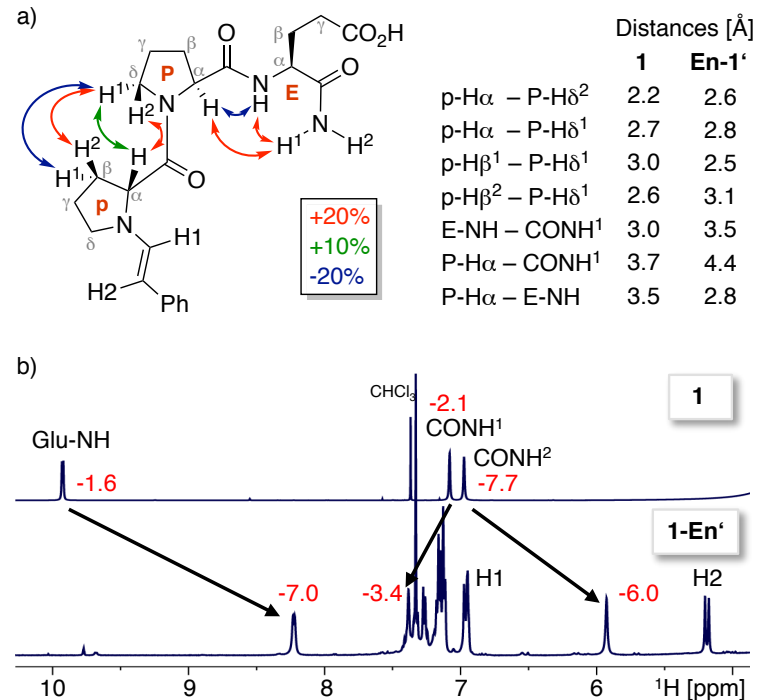

Figure 6. a) Comparison of the NOEs and distances indicative of the $\beta$-turn conformation in peptide $\mathbf{1}$ and enamine $\mathbf{1 - E n ' . ~ b ) ~}$ $500 \mathrm{MHz}{ }^{1} \mathrm{H}$ NMR spectrum of $\mathbf{1}$ (top) and 1-En' (bottom) in $\mathrm{CDCl}_{3}: \mathrm{CD}_{3} \mathrm{OH}$ 9:1 recorded at $-20^{\circ} \mathrm{C}$. Temperature coefficients of amide protons $(\mathrm{ppb} / \mathrm{K})$ determined from spectra recorded between $-60^{\circ} \mathrm{C}$ and $0{ }^{\circ} \mathrm{C}$ in red. 
Destabilization of the $\beta$-turn conformation of 1-En' compared to that of 1 was further corroborated by a significantly higher temperature dependence of the $\mathrm{C}$-terminal $\mathrm{CONH}^{1}$ amide proton chemical shift in enamine 1-En' $(-3.4 \mathrm{ppb} / \mathrm{K})$ than in peptide $1(-2.1 \mathrm{ppb} / \mathrm{K}$, Figure $6 \mathrm{~b})$. In addition, the ${ }^{3} \mathrm{~J}(\mathrm{E}-\mathrm{NH}, \mathrm{E}-$ $\mathrm{H} \alpha$ ) coupling constant, which corresponds to the $\phi$-dihedral angle of the Glu residue, is larger in 1-En' $\left(7.1 \mathrm{~Hz}\right.$, at $-20^{\circ} \mathrm{C}$ ) than in $1\left(5.5 \mathrm{~Hz}\right.$, at $\left.-20^{\circ} \mathrm{C}\right)$. A value of $7.1 \mathrm{~Hz}$ is still in agreement with a dihedral angle close to $270^{\circ}$, expected for a canonical type I $\beta$-turn, ${ }^{38}$ however, ${ }^{3} \mathrm{~J}_{\mathrm{HH}}$-coupling constants of $7-9 \mathrm{~Hz}$ are not diagnostic for folded conformations, since similar values are also expected for unfolded peptides. ${ }^{34,35}$

Conformation of the glutamic acid side chain in enamine 1-En ${ }^{1}$. The glutamic acid side chain $\mathrm{CO}_{2} \mathrm{H}$ group in peptide $\mathbf{1}$ forms a $\mathrm{H}$-bond with the $\mathrm{N}$-terminal amine. This stabilizing interaction is no longer possible in the enamine 1-En' and hence, we expected the side-chain of the Glu residue to exhibit a higher degree of flexibility. The amide $\mathrm{NH}$ of Glu (E-NH) appears at significantly higher field in 1-En' (8.23 ppm at $-20^{\circ} \mathrm{C}$ ) compared to $\mathbf{1}\left(9.93 \mathrm{ppm}\right.$ at $-20^{\circ} \mathrm{C}$, Figure $\left.6 \mathrm{~b}\right)$. This shift to higher field suggests a weakening or loss of the intraresidual $\mathrm{H}$-bond between the $\mathrm{CO}_{2} \mathrm{H}$ group and the amide $\mathrm{NH}$ of the Glu residue. This finding is further corroborated by a low temperature coefficient of $-7.0 \mathrm{ppb} / \mathrm{K}$ observed for $\mathrm{E}$ $\mathrm{NH}$ in 1-En' $(-1.6 \mathrm{ppb} / \mathrm{K}$ in $\mathbf{1})$, which is close to values found for solvent exposed amide protons. ${ }^{48}$ Although the limited stability of 1-En' precluded determination of heteronuclear coupling constants, useful additional information was gained from analysis of the multiplet fine structure in the ${ }^{1} \mathrm{H}$ NMR spectrum. The ${ }^{3} \mathrm{~J}_{\mathrm{H}, \mathrm{H}}$ coupling constants between E-H $\alpha$ and E$\mathrm{H} \beta^{1}$ and $\mathrm{E}-\mathrm{H} \beta^{2}$ are $9.7 \mathrm{~Hz}$ and $3.3 \mathrm{~Hz}$, respectively. ${ }^{61}$ These values are in agreement with a strong preference $(>80 \%)$ of $\mathrm{E}$ $\chi^{1}$ to adopt a torsion angle close to $-60^{\circ}$ or $180^{\circ}$. Regardless of which conformation is mainly populated, the orientation of the glutamic acid residue side chain in 1-En' differs significantly from that of 1 where $E-\chi^{1}$ is exclusively $\sim+60^{\circ}$. The value of the dihedral angle E- $\chi^{2}$ could not be extracted from the NMR data as the signals of $\mathrm{E}-\mathrm{H} \gamma^{1}$ and $\mathrm{E}-\mathrm{H} \gamma^{2}$ are isochronous. ${ }^{62}$ Overall, the data shows that the side chain of the Glu residue undergoes a significant conformational change upon formation of the enamine 1-En' from the ground state catalyst $\mathbf{1}$.

Pyrrolidine ring puckering in enamine 1-En'. Insight into the ring puckers of the proline residues in 1-En' was again gained from the ${ }^{3} \mathrm{~J}\left(\mathrm{H} \alpha, \mathrm{H} \beta^{2}\right)$ couplings of $\mathrm{p} 1$ and $\mathrm{P} 2$. The coupling constants $3.4 \mathrm{~Hz}$ (p1) and $3.3 \mathrm{~Hz}(\mathrm{P} 2)$ are small, which suggests that both residues adopt $\mathrm{C} \gamma$-endo puckers preferentially. This is in contrast to the free catalyst, where only the Pro residue shows a preference for the $\mathrm{C} \gamma$-endo conformation. Signal overlap in the ${ }^{1} \mathrm{H}$ NMR spectrum of 1-En' did not allow for the determination of additional ${ }^{3} \mathrm{~J}_{\mathrm{H}, \mathrm{H}^{-}}$ couplings for more detailed analysis. ${ }^{63}$

Computational structural analysis of enamine 1-En'. The NMR spectroscopic data showed that the enamine 1-En' is more flexible than $\mathbf{1}$ and adopts more than one conformation. Thus, the data does not allow for a classic simulated annealing approach that provides one structure in atomistic detail. We therefore performed computational studies and compared the resulting conformers and their predicted populations with the NMR spectroscopic data. ${ }^{64}$

We used the program MacroModel ${ }^{65}$ with the OPLS3 force field ${ }^{66}$ and the $\mathrm{GB} / \mathrm{SA}$ solvent model for $\mathrm{CHCl}_{3}{ }^{67}$ to sample the conformational space of 1-En'. The calculations started from a random extended conformation and provided 2591 conformers within $10 \mathrm{kcalmol}^{-1}$ of the global minimum. ${ }^{27}$ These conformers were clustered according to the root mean square deviation (RMSD) of the heavy atoms and 39 representative conformers were optimized by DFT using the M06-2X-D3/6-311+G** level of theory. ${ }^{27,68,69}$ The DFT calculations were performed with Gaussian $09^{70}$ using the PCM $\mathrm{CHCl}_{3}$ solvation model. ${ }^{71}$ The Boltzmann populations of the individual conformers were obtained from the free energies calculated by DFT. ${ }^{27}$ In the following, members of the conformational ensemble generated with this procedure will be referred to as "DFT-structures" wherever it is necessary to distinguish them from experimentally-derived structures.

In order to evaluate whether this computational procedure is suitable to reflect results obtained by the NMR-spectroscopic analysis we firstly performed calculations with peptide 1 . The computational studies yielded two closely related lowest energy conformations of $1\left(\Delta \mathrm{E}=0.54 \mathrm{kcalmol}^{-1}\right)$ that account for $>99 \%$ of the Boltzmann population and are very similar to the NMR-spectroscopically derived conformation (all carbon RMSD $=0.42 \AA$ and $0.48 \AA$, Figure S9). The two structures differ essentially only in the pucker of the N-terminal proline ring, where also the NMR-spectroscopic studies had revealed flexibility (vide supra). Thus, the results from the computational studies for peptide $\mathbf{1}$ are in very good agreement with the structure obtained by NMR spectroscopy. ${ }^{27}$

For the peptide-enamine 1-En' the computational protocol yielded a lowest energy structure that accounts for $67 \%$ of the conformational ensemble. This structure is a type I $\beta$-turn with the enamine moiety in a s-trans conformation. An overlay of the lowest energy structures of $\mathbf{1}$ and 1-En' resulting from the conformational searches and DFT optimization shows that they differ significantly in the $\psi$ angle of the DPro residue and the orientation of the glutamic acid side-chain (Figure 7a). a)

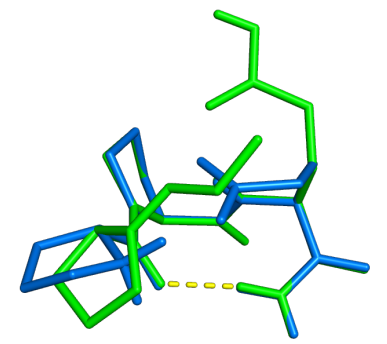

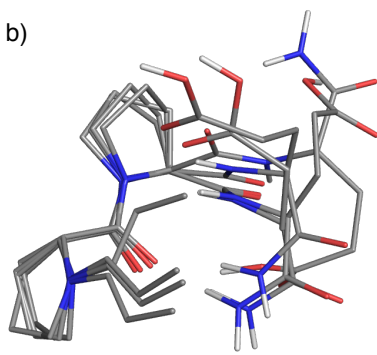

Figure 7. a) Overlay of lowest energy DFT-structures found for 1 (blue) and 1-En' (green). b) Overlay of the four calculated structures within $2 \mathrm{kcalmol}^{-1}$ of the lowest energy structure of 1-En'. For clarity, nonpolar $\mathrm{H}$ atoms and the phenyl moiety of the enamine are not shown 
Amongst all 39 conformers, four are within $2 \mathrm{kcalmol}^{-1}$ of the lowest energy structure and represent more than $96.4 \%$ of the conformational ensemble (Figure 7b). Most conformers adopt a s-trans enamine conformation $(83 \%)$ while the s-cis conformers account for only $17 \%$. The presence of a minor population of s-cis conformers is in agreement with the predicted ratio of $\sim 70: 30$ from the NMR spectroscopic analysis. Most of the lower energy structures (88.7\%) adopt a $\beta$-turn conformation, a $\gamma$-turn is only observed in higher energy structures $(0.1 \%)$. In addition, a significant population $(11 \%)$ of a different conformation was found, in which the carbonyl group of the DPro residue forms a H-bond with the $\mathrm{CO}_{2} \mathrm{H}$ group of the glutamic acid side chain. These findings are in agreement with the NMR data where the large temperature dependence of E-NH excludes a $\gamma$-turn and revealed that other conformations besides a $\beta$-turn must be present in solution.

Based on the available homonuclear coupling constants, we concluded that one of the staggered conformations of E- $\chi 1$ is mainly populated in 1-En' but it was not possible to decide whether it is $\mathrm{E}-\chi^{1}=-60^{\circ}$ or $180^{\circ}$ (vide supra). Now we compared the experimentally-determined coupling constants with the predicted values. To enable this comparison we converted the respective dihedral angles of the DFT-structures into population-weighted J-couplings using the Karplus equation. ${ }^{27}$ The values for ${ }^{3} \mathrm{~J}\left(\mathrm{E}-\mathrm{H} \alpha, \mathrm{E}-\mathrm{H} \beta^{1}\right)$ and ${ }^{3} \mathrm{~J}(\mathrm{E}-\mathrm{H} \alpha, \mathrm{E}-$ $\mathrm{H} \beta^{2}$ ) are $3.1 \mathrm{~Hz}$ and $10.4 \mathrm{~Hz}$, respectively, and close to the experimentally-determined values of $3.3 \mathrm{~Hz}$ and $9.7 \mathrm{~Hz}$. Since conformations with $\mathrm{E}-\chi^{1}=\sim-60^{\circ}$ prevail in the DFT-generated conformational ensemble (94\%), the calculations support this angle as the dominant conformation within the Glu-side chain in 1-En. In the case of the J-coupling between E-NH and E$\mathrm{H} \alpha$, the back-calculated value is $5.8 \mathrm{~Hz}$. This value is closer to the experimental value found for $1(5.5 . \mathrm{Hz})$ than that observed for 1-En' $(7.1 \mathrm{~Hz})$. Since ${ }^{3} \mathrm{~J}_{\mathrm{H}, \mathrm{NH}^{a}}$ values smaller than $7 \mathrm{~Hz}$ point to a distinct preferred conformation, ${ }^{34,35}$ the smaller value back-calculated from the DFT-structures of 1-En' indicates that the conformational flexibility in E- $\phi$ of 1-En' is not sufficiently mirrored by the DFT-derived conformational ensemble.

Finally, we compared the distances derived from the NMR spectroscopic analysis with the population weighted distances obtained from the calculated conformational ensemble. ${ }^{27}$ All of the calculated distances are in agreement with the NOEderived distances when the entire conformational ensemble is taken into account. In contrast, three interresidual distances are violated when the NOE-derived distances were compared only with the distances in the DFT-structure with the lowest energy. This finding demonstrates that the NOE-derived distances observed for 1-En' are in better agreement with an ensemble of different conformations than with that of a single lowest energy structure.

Comparison of the conformations of the ground state and the enamine of 1 - Implications for catalysis. The NMR spectroscopic and computational analyses revealed that peptidic catalyst $\mathbf{1}$ adopts in its ground state a single predominant conformation. This structure is a type I $\beta$-turn conformation, which gains further stabilization from an additional hydrogen bond and a salt-bridge to the glutamic acid side chain carboxylic acid group. Thus, the N-terminal amine, the carboxylic acid and all amide groups are involved in stabilizing interactions and contribute cooperatively to the structural stability of the tripeptide. Upon formation of the enamine, the intramolecular salt-bridge between the $\mathrm{N}$ terminal amine and the carboxylic acid moiety is broken up. This loss of a stabilizing interaction is accompanied by a weakening of the remaining $\mathrm{H}$-bonding interactions and results in a significantly higher conformational flexibility of the enamine intermediate compared to the ground state catalyst 1. A type I $\beta$-turn conformation still dominates the conformational ensemble of 1-En', but the glutamic acid side chain and the backbone of 1-En' are significantly more flexible than in $\mathbf{1}$.

These results show that the peptidic catalyst undergoes a significant structural change upon formation of the key intermediate in the rate- and stereoselectivity-determining step of the reaction (Scheme 2). The $\mathrm{CO}_{2} \mathrm{H}$ moiety within the side chain of the glutamic acid residue plays a crucial role for this change between rigidity and flexibility of the tripeptide. In the ground state, the interaction with the secondary amine stabilizes one predominant conformation. In contrast, this interaction is lost in the enamine. As a result, the conformation of the enamine is sufficiently adaptable to accommodate the incoming nitroolefin for $\mathrm{C}-\mathrm{C}$ bond formation. The conformational change of the peptidic catalyst is accompanied by "opening" and "closing" of the side chain of the glutamic acid residue, similar to a lid that opens and closes. ${ }^{72}$ These insights show that the carboxylic acid moiety serves not only as a proton donor but contributes significantly to the conformational properties of peptidic catalyst $\mathbf{1}$.

Scheme 2. Schematic catalytic cycle depicting toggling between conformations with greater or lesser rigidity of peptidic catalyst $\mathbf{1}$.

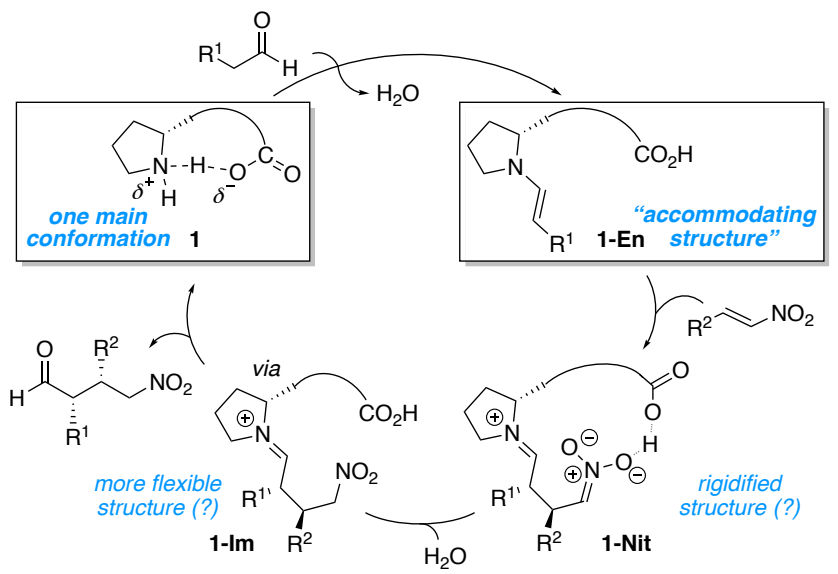

The salt-bridge formed between the carboxylic acid moiety and the $\mathrm{N}$-terminal amine in the ground state might also contribute to the high robustness and ensuing reusability of the catalyst since the protonation shields the reactive amine. ${ }^{73}$ Furthermore, the stability of the zwitterionic ground state of 
the catalyst might also be a driving force for product release from the catalyst.

It is conceivable that the observed alteration between rigidity and flexibility of the ground state of the catalyst and the enamine intermediate continues in the catalytic cycle. Upon reaction of the enamine with the nitroolefin, the imminiumnitronate 1-Nit is protonated intramolecularly by the carboxylic acid group to form imminium ion 1-Im (Schemes 1 and 2). Imminium-nitronates are too reactive to allow for NMR spectroscopic characterization of the conformation of 1Nit, but interaction between the nitronate and the carboxylic acid moiety makes it plausible that the structure of 1-Nit is more rigid than that of the enamine 1-En. Within the resulting imminium ion 1-Im the carboxylic acid is once again lacking an interaction partner and $\mathbf{1 - I m}$ is therefore likely more flexible than either 1-Nit or the ground state catalyst. Thus, our findings suggest that the structure of the peptidic catalyst 1 is sufficiently adaptable to adjust its conformational properties to each state of the catalytic cycle (Scheme 2).

\section{Conclusions}

Detailed NMR spectroscopic analyses, which included RDCs, J-couplings, NOE-derived distances, and temperature coefficients, enabled insight into the conformational properties of the tripeptidic catalyst H-DPro-Pro-Glu- $\mathrm{NH}_{2}$. The studies showed that the peptide adopts in solution a predominant $\beta$ turn conformation with two additional intramolecular H-bonds in its ground state. In contrast, the corresponding enamine still adopts predominantly a $\beta$-turn but is significantly more flexible since the additional $\mathrm{H}$-bonds are weakened or no longer realized. Key to the conformational properties is the carboxylic acid moiety in the side chain of the glutamic acid residue, which acts as a lid that can close to restrict the conformational space of the catalyst or open to allow for an accommodating structure. Thus, the conformation of the peptidic catalyst is sufficiently adaptable to adjust to the steric and stereoelectronic requirements of the intermediates and transition states that form during the catalytic cycle. This modulation of conformational flexibility is likely critical for the catalytic activity of the peptidic catalyst, which is significantly higher compared to other secondary amine-based catalysts. The observed balance between rigidity and flexibility is also reminiscent of the dynamic nature of enzymes, which is recognized as essential for substrate binding, product release, and the need to access competent conformations along the reaction pathway. ${ }^{74,75}$ The presented insights suggest that peptidic catalysts - and other synthetic catalysts of low molecular weight - also benefit from a certain degree of conformational flexibility that allows toggling between rigid and accommodating states during the course of the catalytic cycle.

\section{AUTHOR INFORMATION}

\section{Corresponding Author}

* ebert@,org.chem.ethz.ch

ORCID: 0000-0003-1507-219X

* Helma.Wennemers@org.chem.ethz.ch

ORCID: 0000-0002-3075-5741

\section{Notes}

The authors declare no competing financial interest. Current address of Dr. J. K. Kisunzu: Department of Chemistry and Biochemistry, Colorado College, Colorado Springs, Colorado 80903, United States of America. Dr. J. Duschmalé: HoffmannLaRoche, Basel. Dr. M. Wiesner: Bachem AG, Bubendorf.

\section{ACKNOWLEDGMENT}

We are grateful to the Swiss National Science Foundation (grant 200020_169423) and the Laboratory for Organic Chemistry of ETH Zurich for financial support.

\section{REFERENCES}

(1) For reviews, see: (a) Davie, E. A. C.; Mennen, S. M.; Xu, Y.; Miller, S. J. Chem. Rev. 2007, 107, 5759. (b) Wennemers, H. Chem. Commun. 2011, 47, 12036. (c) Lewandowski, B.; Wennemers, H. Curr. Opin. Chem. Biol. 2014, 22, 40. (d) Fingerhut, A.; Grau, D.; Tsogoeva, S. B. In Sustainable Catalysis: Without Metals or Other Endangered Elements, Part 1; North, M., Ed.; Royal Society of Chemistry: Cambridge, 2016; pp 309-353. (e) Shugrue, C. R.; Miller, S. J. Chem. Rev. 2017, 117, 11894

(2) For selected examples of peptidic catalysts, see: (a) Gustafson, J. L.; Lim, D.; Miller, S. J. Science 2010, 328, 1251. (b) Müller, C. E.; Zell, D.; Hrdina, R.; Wende, R. C.; Wanka, L.; Schuler, S. M. M.; Schreiner, P. R. J. Org. Chem. 2013, 78, 8465. (c) Barrett, K. T.; Metrano, A. J.; Rablen, P. R.; Miller, S. J. Nature 2014, 509, 71. (d) Shugrue C. R.; Miller S. J. Angew. Chem. Int. Ed. 2015, 54, 11173. (e) Alford, J. S.; Abascal, N. C.; Shugrue, C. R.; Colvin, S. M.; Romney, D. K.; Miller, S. J. ACS Cent. Sci. 2016, 2, 733.

(3) For selected examples of peptidic catalysts for $\mathrm{C}-\mathrm{C}$ bond formation reactions, see: (a) Martin, H. J.; List, B. Synlett 2003, 1901. (b) Freund, M.; Schenker, S.; Tsogoeva, S. B. Org. Biomol. Chem. 2009, 7, 4279. (c) Akagawa, K.; Kudo, K. Angew. Chem. Int. Ed. 2012, 51, 12786. (f) Mbofana, C. T.; Miller, S. J. J. Am. Chem. Soc. 2014, 136, 3285. (d) Akagawa, K.; Sakai, N.; Kudo, K. Angew. Chem. Int. Ed. 2015, 54, 1822. (e) Wende R. C.; Seitz, A.; Niedek, D.; Schuler S. M. M.; Hofmann, C.; Becker, J.; Schreiner P. R. Angew. Chem. Int. Ed. 2016, 55, 2719. (f) Illa, O.; Porcar-Tost, O.; Robledillo, C.; Elvira, C.; Nolis, P.; Reiser, O.; Branchadell, V.; Ortuño, R. M. J. Org. Chem. 2018, 83, 350.

(4) For selected examples of site-selective peptidic catalysts, see: (a) Lewis C. A.; Miller S. J. Angew. Chem. Int. Ed. 2006, 45, 5616. (b) Fowler, B. S.; Laemmerhold, K. M.; Miller, S. J. J. Am. Chem. Soc. 2012, 134, 9755. (c) Lichtor, P. A.; Miller, S. J. Nature Chem. 2012, 4, 990. (d) Han, S.; Miller, S. J. J. Am. Chem. Soc. 2013, 135, 12414. 
(5) (a) Krattiger, P.; Kovasy, R.; Revell, J. D.; Ivan, S.; Wennemers, H. Org. Lett. 2005, 7, 1101. (b) Revell, J. D.; Wennemers, H. Adv. Synth. Catal. 2008, 350, 1046. (c) Messerer, M.; Wennemers, H. Synlett 2011, 499.

(6) Wiesner, M.; Neuburger, M.; Wennemers, H. Chem. Eur. J. 2009, 15, 10103.

(7) (a) Wiesner, M.; Revell, J. D.; Wennemers, H. Angew. Chem. Int. Ed. 2008, 47, 1871. (b) Wiesner, M.; Revell, J. D.; Tonazzi, S.; Wennemers, H. J. Am. Chem. Soc. 2008, 130, 5610 .

(8) Wiesner, M.; Upert, G.; Angelici, G.; Wennemers, H. J. Am. Chem. Soc. 2010, 132, 6.

(9) Duschmalé, J.; Wennemers, H. Chem. Eur. J. 2012, 18, 1111.

(10) Kastl, R.; Wennemers, H. Angew. Chem. Int. Ed. 2013, 52,7228 .

(11) (a) Grünenfelder, C. E.; Kisunzu, J. K.; Wennemers, H. Angew. Chem. Int. Ed. 2016, 55, 8571. (b) Schnitzer, T.; Wennemers, H. Synlett 2017, 28, 1282.

(12) (a) Marshall, G. R.; Beusen, D. D.; Nikiforovich, G. V. Peptide Conformation: Stability and Dynamics; Academic Press: San Diego, 1995; pp 193-245. (b) Romero Romero, M. L.; Rabin, A.; Tawfik, D. S. Angew. Chem. Int. Ed. 2016, 55, 15966. (c) Baker, E. G.; Bartlett, G. J.; Porter Goff, K. L.; Woolfson, D. N. Acc. Chem. Res. 2017, 50, 2085.

(13) (a) Abascal, N. C.; Lichtor, P. A.; Giuliano, M. W.; Miller, S. J. Chem. Sci. 2014, 5, 4504. (b) Abascal, N. C.; Miller, S. J. Org. Lett. 2016, 18, 4646.

(14) Metrano, A. J.; Abascal, N. C.; Mercado, B. Q.; Paulson, E. K.; Hurtley, A. E.; Miller, S. J. J. Am. Chem. Soc. 2017, 139, 492.

(15) Crawford, J. M.; Stone, E. A.; Metrano, A. J.; Miller, S. J.; Sigman, M. S. J. Am. Chem. Soc. 2018, 140, 868.

(16) Procházková, E.; Kolmer, A.; Ilgen, J.; Schwab, M.; Kaltschnee, L.; Fredersdorf, M.; Schmidts, V.; Wende, R. C.; Schreiner, P. R.; Thiele, C. M. Angew. Chem. Int. Ed. 2016, 55,15754 .

(17) (a) List, B.; Lerner, R. A.; Barbas III, C. F. J. Am. Chem. Soc. 2000, 122, 2395. (b) For a review see: Mukherjee, S.; Yang, J. W.; Hoffmann, S.; List, B. Chem. Rev. 2007, 107, 5471. (c) Science of Synthesis, Asymmetric Organocatalysis; List, B.; Maruoka, K., Eds.; Georg Thieme Verlag: Stuttgart, 2012.

(18) (a) Arakawa, Y.; Wiesner, M.; Wennemers, H. Adv. Synth. Catal. 2011, 353, 1201. (b) Arakawa, Y.; Wennemers, H. ChemSusChem 2013, 6, 242.

(19) (a) Atodiresei, I.; Vila, C.; Rueping, M. ACS Catal. 2015, 5, 1972. (b) Tsubogo, T.; Ishiwata, T.; Kobayashi, S. Angew. Chem. Int. Ed. 2013, 52, 6590. (c) Rodríguez-Escrich, C.; Pericàs M. A. Eur. J. Org. Chem. 2015, 1173.

(20) Bächle, F.; Duschmalé, J.; Ebner, C.; Pfaltz, A.; Wennemers, H. Angew. Chem. Int. Ed. 2013, 52, 12619.

(21) Duschmalé, J.; Wiest, J.; Wiesner, M.; Wennemers, H. Chem. Sci. 2013, 4, 1312.
(22) Note, structure activity relationship studies with analogs of peptide 1 showed that the carboxylic acid moiety and its position are important for the reactivity and stereoselectivity. See for examples, ref. 5b, 6 and 21.

(23) Schnitzer, T.; Wennemers, H. J. Am. Chem. Soc. 2017, 139,15356 .

(24) Grünenfelder, C. E.; Kisunzu, J. K.; Trapp, N.; Kastl, R.; Wennemers, H. Pept. Sci. 2017, 108, e22912.

(25) Renzi, P.; Hioe, J.; Gschwind, R. M. Acc. Chem. Res. 2017, 50, 2936 .

(26) The spectra were recorded at a concentration of $30 \mathrm{mM}$, a concentration that is six fold higher compared to the concentration used for the catalytic reactions $(5 \mathrm{mM})$ but allowed us to obtain meaningful data within a reasonable time frame.

(27) For details, see the Supporting Information.

(28) Cai, M.; Huang, Y.; Liu, J.; Krishnamoorthi, R. J. Biomol. NMR 1995, 6, 123.

(29) (a) Nair, C. M. K.; Vijayan, M. J. Chem. Soc., Perkin Trans. 2 1980, 1800. (b) Bean, J. W.; Kopple, K. D.; Peishoff, C. E. J. Am. Chem. Soc. 1992, 114, 5328. (c) Chalmers, D. K.; Marshall, G. R. J. Am. Chem. Soc. 1995, 117, 5927. (d) Rai, R.; Aravinda, S.; Kanagarajadurai, K.; Raghothama, S.; Shamala, N.; Balaram, P. J. Am. Chem. Soc. 2006, 128, 7916. (e) Chatterjee, B.; Saha, I.; Raghothama, S.; Aravinda, S.; Rai, R.; Shamala, N.; Balaram, P. Chem. Eur. J. 2008, 14, 6192.

(30) (a) Favre, M.; Moehle, K.; Jiang, L.; Pfeiffer, B.; Robinson, J. A. J. Am. Chem. Soc. 1999, 121, 2679. (b) Shankaramma, S. C.; Athanassiou, Z.; Zerbe, O.; Moehle, K.; Mouton, C.; Bernardini, F.; Vrijbloed, J. W.; Obrecht, D.; Robinson, J. A. ChemBioChem 2002, 3, 1126.

(31) Robinson, J. A. Acc. Chem. Res. 2008, 41, 1278.

(32) Rai, R.; Raghothama, S.; Balaram, P. J. Am. Chem. Soc. 2006, 128,2675

(33) Wüthrich, K.; Billeter, M.; Braun, W. J. Mol. Biol. 1984, 180,715 .

(34) Dyson, H. J.; Wright, P. E. Annu. Rev. Biophys. Biophys. Chem. 1991, 20, 519

(35) Dyson, H. J.; Bolinger, L.; Feher, V. A.; Osterhout, J. J.; Yao, J.; Wright, P. E. Eur. J. Biochem. 1998, 255, 462.

(36) (a) Koźmiński, W.; Nanz, D. J. Magn. Reson. 2000, 142, 294. (b) Zhu, G.; Bax, A. J. Magn. Reson., Ser. A 1993, 104, 353. (c) Cicero, D. O.; Barbato, G.; Bazzo, R. J. Magn. Reson. 2001, 148, 209

(37) Wang, A. C.; Bax, A. J. Am. Chem. Soc. 1996, 118, 2483. (38) (a) Hutchinson, E. G.; Thornton, J. M., Protein Sci. 1994 3, 2207. (b) Wilmot, C. M.; Thornton, J. M. J. Mol. Biol. 1988, 203, 221 .

(39) (a) Pérez, C.; Löhr, F.; Rüterjans, H.; Schmidt, J. M. J. Am. Chem. Soc. 2001, 123, 7081. (b) Altona, C.; Francke, R.; de Haan, R.; Ippel, J. H.; Daalmans, G. J.; Hoekzema, A. J. A. W.; van Wijk, J. Magn. Reson. Chem. 1994, 32, 670. (c) Aydin, R.; Günther, H. Magn. Reson. Chem. 1990, 28, 448. (d) Altona, C.; Ippel, J. H.; Hoekzema, A. J. A. W.; Erkelens, C.; 
Groesbeek, M.; Donders, L. A. Magn. Reson. Chem. 1989, 27, 564.

(40) (a) Saupe, A.; Englert, G. Phys. Rev. Lett. 1963, 11, 462. (b) Tolman, J. R.; Flanagan, J. M.; Kennedy, M. A.; Prestegard, J. H. Proc. Natl. Acad. Sci. USA 1995, 92, 9279. (c) Tjandra, N.; Bax, A. Science 1997, 278, 1111. (d) Tycko, R.; Blanco, F. J.; Ishii, Y. J. Am. Chem. Soc. 2000, 122, 9340.

(41) For reviews on the use of RDCs for small molecules, see: (a) Gil, R. R. Angew. Chem. Int. Ed. 2011, 50, 7222. (b) Kummerlöwe, G.; Luy, B. Annu. Rep. NMR Spectrosc. 2009, 68, 193. (c) Thiele, C. M. Eur. J. Org. Chem. 2008, 2008, 5673. (d) Schmidts, V. Magn. Reson. Chem. 2017, 55, 54. (e) Kummerlöwe, G.; Luy, B. Trends Anal. Chem. 2009, $28,483$. (f) Gil, R. R.; Griesinger, C.; Navarro-Vázquez, A.; Sun, H., Structural Elucidation of Small Organic Molecules Assisted by NMR in Aligned Media. In Structure Elucidation in Organic Chemistry, Wiley-VCH Verlag GmbH \& Co. KGaA: 2015; 279-324. For reviews on the use of RDCs for proteins, see: (g) Prestegard, J. H.; Al-Hashimi, H. M.; Tolman, J. R. Quart. Rev. Biophys. 2000, 33, 371. (h) Prestegard, J. H.; Bougault, C. M.; Kishore, A. I. Chem. Rev. 2004, 104, 3519. (i) Blackledge, M. Prog. Nucl. Magn. Reson. Spectrosc. 2005, 46, 23. (j) Tolman, J. R.; Ruan, K. Chem. Rev. 2006, 106, 1720 .

(42) For selected examples on conformational analysis of peptides using RDCs, see (a) Klages, J.; Neubauer, C.; Coles, M.; Kessler, H.; Luy, B. ChemBioChem 2005, 6, 1672. (b) Reinscheid, U. M.; Farjon, J.; Radzom, M.; Haberz, P.; Zeeck, A.; Blackledge, M.; Griesinger, C. ChemBioChem 2006, 7, 287. (c) Kiran, M. U.; Sudhakar, A.; Klages, J.; Kummerlöwe, G.; Luy, B.; Jagadeesh, B. J. Am. Chem. Soc. 2009, 131, 15590. (d) Schmid Markus, B.; Fleischmann, M.; D'Elia, V.; Reiser, O.; Gronwald, W.; Gschwind R. M. ChemBioChem 2009, 10, 440. (e) Fredersdorf, M.; Kurz, M.; Bauer, A.; Ebert, M.-O.; Rigling, C.; Lannes, L.; Thiele, C. M. Chem.Eur. J. 2017, 23, 5729. (f) Rigling, C.; Ebert, M.-O. Magn. Reson. Chem. 2017, 55, 655 .

(43) Freudenberger, J. C.; Knör, S.; Kobzar, K.; Heckmann, D.; Paululat, T.; Kessler, H.; Luy, B. Angew. Chem. Int. Ed. 2005, 44, 423.

(44) (a) Schwieters, C. D.; Kuszewski, J. J.; Tjandra, N.; Clore, G. M. J. Magn. Reson. 2003, 160, 65. (b) Sass, H.-J.; Musco, G.; Stahl, S. J.; Wingfield, P. T.; Grzesiek, S. J. Biomol. NMR 2001, 21, 275. (c) Moltke, S.; Grzesiek, S. J. Biomol. NMR 1999, 15, 77.

(45) Levitt, M. J. Mol. Biol. 1983, 170, 723.

(46) For examples, see: (a) Stevens, E. S.; Sugawara, N.; Bonora, G. M.; Toniolo, C. J. Am. Chem. Soc. 1980, 102, 7048. (b) Wagner, G.; Pardi, A.; Wuethrich, K. J. Am. Chem. Soc. 1983, 105, 5948. (c) Gellman, S. H.; Dado, G. P.; Liang, G. B.; Adams, B. R. J. Am. Chem. Soc. 1991, 113, 1164. (d) Merutka, G.; Jane Dyson, H.; Wright, P. E. J. Biomol. NMR 1995, 5, 14. (e) Baxter, N. J.; Williamson, M. P., J. Biomol. NMR 1997, 9, 359. (f) Gademann, K.; Jaun, B.; Seebach, D.; Perozzo, R.; Scapozza, L.; Folkers, G. Helv. Chim. Acta 1999, 82, 1. (g) Wang, C. K.; Northfield, S. E.; Colless, B.; Chaousis, S.; Hamernig, I.; Lohman, R.-J.; Nielsen, D. S.;
Schroeder, C. I.; Liras, S.; Price, D. A.; Fairlie, D. P.; Craik, D. J. Proc. Natl. Acad. Sci. USA 2014, 111, 17504.

(47) Andersen, N. H.; Neidigh, J. W.; Harris, S. M.; Lee, G. M.; Liu, Z.; Tong, H. J. Am. Chem. Soc. 1997, 119, 8547.

(48) Cierpicki, T.; Otlewski, J. J. Biomol. NMR 2001, 21, 249.

(49) Based on an extensive analysis of amide protons in proteins, Cierpicki and Otlewski found that H-bonded amides typically have a temperature coefficient of $>-4.6 \mathrm{ppb} / \mathrm{K}$; see ref. 48 .

(50) (a) Dingley, A. J.; Masse, J. E.; Peterson, R. D.; Barfield, M.; Feigon, J.; Grzesiek, S. J. Am. Chem. Soc. 1999, 121, 6019. (b) Limbach, H.-H.; Pietrzak, M.; Sharif, S.; Tolstoy, P. M.; Shenderovich, I. G.; Smirnov, S. N.; Golubev, N. S.; Denisov, G. S. Chem. Eur. J. 2004, 10, 5195.

(51) (a) Haasnoot, C. A. G.; De Leeuw, F. A. A. M.; De Leeuw, H. P. M.; Altona, C. Biopolymers 1981, 20, 1211. (b) Ho, B. K.; Coutsias, E. A.; Seok, C.; Dill, K. A. Protein Sci. 2005, 14, 1011 .

(52) (a) Bretscher, L. E.; Jenkins, C. L.; Taylor, K. M.; DeRider, M. L.; Raines, R. T. J. Am. Chem. Soc. 2001, 123, 777. (b) Sonntag, L.-S.; Schweizer, S.; Ochsenfeld, C.; Wennemers, H. J. Am. Chem. Soc. 2006, 128, 14697. (c) Pandey, A. K.; Naduthambi, D.; Thomas, K. M.; Zondlo, N. J. J. Am. Chem. Soc. 2013, 135, 4333.

(53) Stork, G.; Brizzolara, A.; Landesman, H.; Szmuszkovicz, J.; Terrell, R. J. Am. Chem. Soc. 1963, 85, 207.

(54) For NMR-spectroscopic studies of enamines derived from organocatalysts, see: (a) Schmid, M. B.; Zeitler, K.; Gschwind, R. M. Angew. Chem. Int. Ed. 2010, 49, 4997. (b) Schmid, M. B.; Zeitler, K.; Gschwind, R. M. J. Am. Chem. Soc. 2011, 133, 7065. (c) Schmid, M. B.; Zeitler, K.; Gschwind, R. M. J. Org. Chem. 2011, 76, 3005. (d) Schmid, M. B.; Zeitler, K.; Gschwind, R. M. Chem. Eur. J. 2012, 18, 3362. (e) Haindl, M. H.; Hioe, J.; Gschwind, R. M. J. Am. Chem. Soc. 2015, 137, 12835. (f) Seebach, D.; Sun, X.; Ebert, M.-O.; Schweizer, W. B.; Purkayastha, N.; Beck, A. K.; Duschmalé, J.; Wennemers, H.; Mukaiyama, T.; Benohoud, M.; Hayashi, Y.; Reiher, M. Helv. Chim. Acta 2013, 96, 799.

(55) Schmid, M. B.; Zeitler, K.; Gschwind, R. M. Chem. Sci. 2011, 2, 1793.

(56) For crystal structures of enamines, see: (a) Seebach, D.; Grošelj, U.; Badine, D. M.; Schweizer, W. B.; Beck A. K. Helv. Chim. Acta 2008, 91, 1999. (b) Grošelj, U.; Seebach, D.; Badine, D. M.; Schweizer, W. B.; Beck A. K.; Krossing, I.; Klose, P.; Hayashi, Y.; Uchimaru, T. Helv. Chim. Acta 2009, 92, 1225. (c) Brown K. L.; Damm, L.; Dunitz J. D.; Eschenmoser, A.; Hobi, R.; Kratky, C. Helv. Chim. Acta 1978, 61, 3108. (d) Bock, D. A.; Lehmann, C. W.; List, B. Proc. Natl. Acad. Sci. USA 2010, 107, 20636.

(57) For a review on computational studies on enamines derived from organocatalysts, see: Cheong, P. H.-Y.; Legault, C. Y.; Um, J. M.; Çelebi-Ölçüm, N.; Houk, K. N. Chem. Rev. 2011, 111, 5042.

(58) Husch, T.; Seebach, D.; Beck, A. K.; Reiher, M. Helv. Chim. Acta 2017, 100, e1700182. 
(59) For studies where an enamine derived from an acidcontaining organocatalyst has been observed in a protic solvent by NMR spectroscopy, see ref. 23 and Cortes-Clerget, M.; Jover, J.; Dussart, J.; Kolodziej, E.; Monteil, M.; MigianuGriffoni, E.; Gager, O.; Deschamp, J.; Lecouvey, M. Chem. Eur. J. 2017, 23, 6654.

(60) Among the side products were compounds formed between the catalyst and homoaldol products that were not observed under catalytic conditions and when a nitroolefin was in the mixture.

(61) These coupling constants were determined from the E-H $\alpha$ multiplet in the ${ }^{1} \mathrm{H} \mathrm{NMR}$ spectrum at $-10^{\circ} \mathrm{C}$. At $-20^{\circ} \mathrm{C}$, signal overlap with the solvent signal precludes the extraction of coupling constants.

(62) In the spectra of $\mathbf{1}$, the chemical shifts of these two protons differ significantly, which further indicates higher flexibility of the Glu side chain of 1-En ${ }^{1}$.

(63) The spectrum was measured at $-20^{\circ} \mathrm{C}$.

(64) Willoughby, P. H.; Jansma, M. J.; Hoye, T. R. Nat. Protoc. 2014, 9, 643.

(65) Schrödinger, LLC, Schrödinger Release 2015-4: MacroModel, version 11.0; New York, NY, 2015.

(66) Harder, E.; Damm, W.; Maple, J.; Wu, C.; Reboul, M.; Xiang, J. Y.; Wang, L.; Lupyan, D.; Dahlgren, M. K.; Knight, J. L.; Kaus, J. W.; Cerutti, D. S.; Krilov, G.; Jorgensen, W. L.; Abel, R.; Friesner, R. A. J. Chem. Theory. Comput. 2016, 12, 281.

(67) (a) Still, W. C.; Tempczyk, A.; Hawley, R. C.; Hendrickson, T. J. Am. Chem. Soc. 1990, 112, 6127. (b) Qiu, D.; Shenkin, P. S.; Hollinger, F. P.; Still, W. C. J. Phys. Chem. A 1997, 101, 3005 .

(68) Kelley, L. A.; Gardner, S. P.; Sutcliffe, M. J. Protein Eng. 1996, 9, 1063.

(69) (a) Grimme, S.; Antony, J.; Ehrlich, S.; Krieg, H. J. Chem. Phys. 2010, 132, 154104. (b) Grimme, S.; Ehrlich, S.; Goerigk, L. J. Comput. Chem. 2011, 32, 1456. (c) Zhao, Y.; Truhlar, D. G., Theor. Chem. Acc. 2008, 120, 215. (d) Krishnan, R.; Binkley, J. S.; Seeger, R.; Pople, J. A. J. Chem. Phys 1980, 72, 650. (e) McLean, A. D.; Chandler, G. S. J. Chem. Phys 1980, 72, 5639.

(70) Frisch, M. J.; Trucks, G. W.; Schlegel, H. B.; Scuseria, G. E.; Robb, M. A.; Cheeseman, J. R.; Scalmani, G.; Barone, V.; Mennucci, B.; Petersson, G. A.; Nakatsuji, H.; Caricato, M.; Li, X.; Hratchian, H. P.; Izmaylov, A. F.; Bloino, J.; Zheng, G.; Sonnenberg, J. L.; Hada, M.; Ehara, M.; Toyota, K.; Fukuda, R.; Hasegawa, J.; Ishida, M.; Nakajima, T.; Honda, Y.; Kitao, O.; Nakai, H.; Vreven, T.; Montgomery, J. A.; Jr., J. E. P.; Ogliaro, F.; Bearpark, M.; Heyd, J. J.; Brothers, E.; Kudin, K. N.; Staroverov, V. N.; Keith, T.; Kobayashi, R.; Normand, J.; Raghavachari, K.; Rendell, A.; Burant, J. C.; Iyengar, S. S.; Tomasi, J.; Cossi, M.; Rega, N.; Millam, J. M.; Klene, M.; Knox, J. E.; Cross, J. B.; Bakken, V.; Adamo, C.; Jaramillo, J.; Gomperts, R.; Stratmann, R. E.; Yazyev, O.; Austin, A. J.; Cammi, R.; Pomelli, C.; Ochterski, J. W.; Martin, R. L.; Morokuma, K.; Zakrzewski, V. G.; Voth, G. A.; Salvador, P.; Dannenberg, J. J.; Dapprich, S.; Daniels, A. D.;
Farkas, O.; Foresman, J. B.; Ortiz, J. V.; Cioslowski, J.; Fox, D. J. Gaussian 09, Revision D.01; Gaussian, Inc., Wallingford CT, 2013.

(71) Tomasi, J.; Mennucci, B.; Cammi, R. Chem. Rev. 2005, 105, 2999.

(72) Analogs of peptide 1 where the carboxylic acid is attached to a longer or shorter side chain are less reactive and stereoselective catalysts than is $\mathbf{1}$, see for example refs. $6,21$.

(73) Of note, these insights show that the catalytic cycle is initiated by protonation of the aldehyde by the zwitterionic catalyst to form the enamine intermediate.

(74) (a) Benkovic, S. J.; Hammes-Schiffer, S. Science 2003, 301, 1196. (b) Bruice, T. C.; Benkovic, S. J. Biochemistry 2000, 39, 6267. (c) Kirby, A. J., Angew. Chem. Int. Ed. 1996, 35, 707. (d) Knowles, J. R. Nature 1991, 350, 121. (e) Smith, A. J. T.; Müller, R.; Toscano, M. D.; Kast, P.; Hellinga, H. W.; Hilvert, D.; Houk, K. N. J. Am. Chem. Soc. 2008, 130, 15361. (f) Warshel, A.; Sharma, P. K.; Kato, M.; Xiang, Y.; Liu, H.; Olsson, M. H. M. Chem. Rev. 2006, 106, 3210.

(75) (a) Boehr, D. D.; Dyson, H. J.; Wright, P. E. Chem. Rev. 2006, 106, 3055. (b) Boehr, D. D.; McElheny, D.; Dyson, H. J.; Wright, P. E. Science 2006, 313, 1638. (c) Callender, R.; Dyer, R. B. Acc. Chem. Res. 2015, 48, 407. (d) Hammes, G. G.; Benkovic, S. J.; Hammes-Schiffer, S. Biochemistry 2011, 50, 10422. (e) Henzler-Wildman, K.; Kern, D. Nature 2007, 450, 964. (f) Kohen, A. Acc. Chem. Res. 2015, 48, 466. (g) Nagel, Z. D.; Klinman, J. P. Nat. Chem. Biol. 2009, 5, 543. 
Suggested TOC Graphic

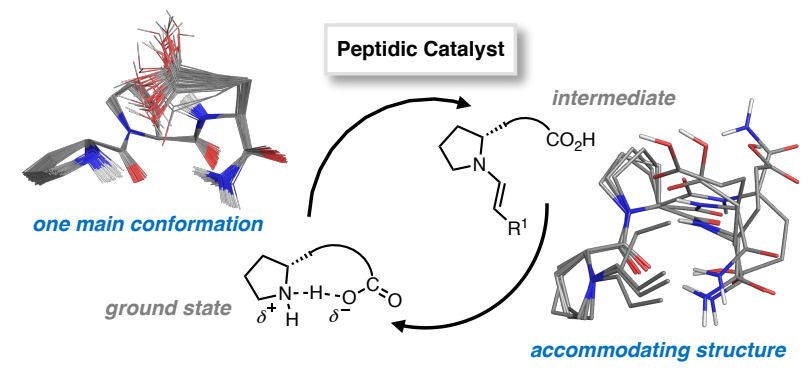

NOEs, J-couplings, RDCs, Temperature coefficients, Computational Methods 